\title{
EFEKTIVITAS UNDANG-UNDANG NO. 35 TAHUN 2009 DALAM TINDAK PIDANA NARKOTIKA
}

\author{
I Putu Suputra, Sagung Laksmi Dewi, Luh Putu Suryani \\ Fakultas Ilmu Hukum Universitas Warmadewa, Denpasar - Bali, Indonesia \\ iputusuputra3@gmail.com, laksmiidewi29@gmail.com, putusuryani099@gmail.com
}

\begin{abstract}
Abstrak
Saat ini penyalahgunaan narkoba di Indonesia sangat merajalela. Dampak negatif yang ditimbulkan sangat besar. Pengawasan dan pengendalian sebagai upaya memberantas dan mencegah peredaran serta penyalahgunaan narkotika sangat diperlukan dikarenakan kejahatan dibidang ini terus berkembang dari segi kualitas maupun kuantitas yang berujung pada rusaknya generasi muda harapan bangsa. Penelitian ini dilakukan dengan tujuan mendeskripsikan bagaimana penerapan sanksi terhadap tindak pidana narkotika dalam putusan Nomor 564/Pid.Sus/2018/PN.DPS dan bagaimana pertimbangan hakim pada penerapan sanksi dalam Putusan Tindak Pidana Narkotika dalam Putusan Nomor 564/Pid.Sus/2018/PN.DPS. Penelitian ini menggunakan metode penelitian hukum normatif. Hasil penelitian ini menunjukkan bahwa penerapan sanksi pidana narkotika yang khususnya dalam putusan nomor 564/Pid.Sus/2018/PN.DPS sudah sesuai dengan apa yang tertuang dalam Undang-Undang No. 35 Tahun 2009 tentang Narkotika dengan berbagai jeratan pasal dan sanksi hukum yang keras sesuai dengan pelanggarannya sebagai bukti keseriusan pemerintah dalam memberikan efek jera, menjaga, menanggulangi serta menyelamatkan atau melindungi generasi bangsa dari bahaya narkotika. Selain itu, pertimbangan hakim dalam menjatuhkan putusan terhadap tindak pidana narkotika dalam putusan nomor 564/Pid.Sus/2018/PN.DPS telah sesuai dengan berdasarkan pada keterangan saksi-saksi, barang bukti, dimana pembuktian memerlukan alat bukti minimal 2 (dua) untuk mempertimbangkan suatu fakta yang ada dalam persidangan, serta dibantu dengan keputusan hakim yang nantinya akan memutuskan suatu perkara tersebut.
\end{abstract}

Kata Kunci: Narkotika; Tindak Pidana; Undang-Undang Narkotika

\begin{abstract}
Currently, drugs in Indonesia are very rampant. The negative impact caused was enormous. Supervision and control as an effort to eradicate and prevent the circulation of narcotics are indispensable for crimes in this field that continue to develop in terms of quality and quantity which lead to the destruction of the nation's generation. This research was conducted with the aim of describing the application of sanctions against narcotics crimes in decision Number 564 / Pid.Sus / 2018 / PN.DPS and the judge's consideration on the application of sanctions in the Narcotics Crime Decision in Decision Number 564 / Pid.Sus / 2018 / PN.DPS. This research used a normative legal research method. The results of this study indicated that the application of narcotics criminal sanctions, especially in decision number 564 / Pid.Sus / 2018 / PN.DPS is in accordance with what is stipulated in Law No. 35 of 2009 concerning Narcotics with various articles of bondage and strict laws in accordance with the evidence as evidence of the government's seriousness in providing a deterrent effect, safeguarding, overcoming, and saving or protecting a nation from the dangers of narcotics. In addition, the judge's consideration in making a decision on narcotics crime in decision number 564 / Pid.Sus / 2018 / PN.DPS is in accordance with the evidence, where proof requires at least 2 (two) evidence to consider a fact that is in the trial and is assisted by a judge's decision who will later decide on a case.
\end{abstract}

Keywords: Narcotics; Crime; Narcotics Law

\section{PENDAHULUAN}

Narkotika adalah zat yang membuat seseorang kecanduan. Narkotika dan psikotropika sejatinya merupakan obat atau zat yang bermanfaat bagi manusia dalam hal pengobatan, pengembangan ilmu pengetahuan, pelayanan kesehatan walaupun pada sisi lain zat ini akan mengakibatkan kerugian yang sangat besar bila disalahgunakan oleh masyarakat dan tanpa adanya kendali dan pengawasan yang baik (Yamin, 2012). 
Permasalahan yang selalu susah dihilangkan dari dulu adalah penyalahgunaan obat-obatan terlarang Zat-zat yang terkandung dalam narkotika yang digunakan untuk kepentingan pengobatan. Perkembangan teknologi dan ilmu pengetahuan mengakibatkan jenis-jenis narkotika dapat diproduksi begitu banyak serta disalahgunakannya fungsi dari narkotika tersebut (Taufik \& Suhasril, 2005). Dalam dunia kedokteran terjadi suatu penyimpangan, yaitu mengenai fungsi dan penggunaan obatobatan terlarang yang sangat terbatas. Namun saat ini hal tersebut sudah lumrah dan menjadi bebas karena dilakukan untuk tujuan terbatas yaitu pengobatan.

Pada masa ini, tidak sedikit kemungkinan orang sehat tidak minum obat- obatan terlarang. Orang yang menggunakan obat-obatan terlarang itu ada banyak jenis. Hingga saat ini hal tersebut menyebar bahkan ke orang remaja pula. Awalnya obat tersebut digunakan sebagai obat penahan rasa sakit, namun lama kelamaan menjadi obat-obatan biasa yangg sering dikonsumsi. Peredaran dan penyalahgunaan narkotika dan obat-obatan terlarang telah terjadi di seluruh kalangan dan generasi di Indonesia yang dilakukan baik sengaja maupun tidak disengaja dengan mengkonsumsi zat adiktif narkotika yang ada dalam obat-obatan tersebut (Amanda, Humaedi, \& Santoso, 2017).

Pengawasan dan pengendalian sebagai bentuk upaya memberantas dan mencegah peredaran narkotika sangat diperlukan karena kejahatan dibidang ini terus berkembang dari segi kualitas maupun kuantitas yang berujung pada rusaknya generasi muda harapan bangsa (Asyharudddin, Badaru, \& Hidjaz, 2020; Suyatna, 2018). Perkembangan kuantitas pemakai narkotika dan kualitas tindak pidana narkotika inilah yang membuat bahaya bagi kehidupan manusia, dan sangat besar resikonya jika manusia sudah terjerumus ke dalam hal tersebut, khususnya generasi muda saat ini yang mudah kehilangan ahklak dan nilai budaya dan bangsa Indonesia.

Namun yang lebih memperihatinkan adalah penyalahgunaan narkoba saat ini justru banyak dari kalangan remaja dan anak muda, yaitu para pelajar (Nurmaya, 2016). Melihat keadaan dan kondisi seperti ini, semua masyarakat Indonesia harus menjauhkan diri dengan yang namanya obat-obatan terlarang. Kebanyakan dari mereka masih duduk di bangku sekolah. Awal mulanya mereka ditawari, dibujuk dan ditekan oleh sekelompok orang yang seusia dengan mereka. Selain itu, stres yang dialami juga sebagai penyebab, dan orang tua yang kurang memberi perhatian pada anak serta permasalahan rumah tangga. Faktor lain adalah rasa ingin tahu, mencoba-coba ataupun ingin memakainya, dan tawaran itu diterima oleh mereka. Hal itu terus berlanjut sehingga mereka menjadi ketergantungan pada obat-obatan terlarang tersebut.

Berdasarkan uraian latar belang di atas, penelitian ini dilakukan dengan beberapa tujuan yaitu: pertama, mendeskripsikan bagaimana penerapan sanksi terhadap tindak pidana narkotika dalam putusan Nomor 564/Pid.Sus/2018/PN.DPS, dan kedua menggambarkan bagaimana pertimbangan hakim pada penerapan sanksi dalam Putusan Tindak Pidana Narkotika dalam Putusan Nomor 564/Pid.Sus/2018/PN.DPS.

\section{METODE PENELITIAN}

Penelitian ini didesain dengan menggunakan metode penelitian hukum normatif. Penelitian ini bertujuan mengungkap norma-norma atau kaidah hukum yang ada dalam peraturan perundangundangan maupun adat istiadat. Sumber data penelitian ini terdiri dari bahan hukum primer yang berupa bahan hukum mengikat dan terdiri dari norma atau kaidah dasar, dan peraturang perundangundangan, bahan hukum sekunder yang berupa bahan yang memberikan penjelasan mengenai bahan hukum primer dan terdiri dari rancangan undang-undang, hasil penelitian, dan pendapat para ahli hukum, dan bahan hukum tersier yang memberikan petunjuk atau penjelasan tentang bahan hukum primer dan skunder, contohnya kamus hukum. Data yang dibutuhkan diperoleh dengan menggunakan metode kajian pustaka. Analisis data dilakukan dengan menggunakan metode kualitatif dan disajikan secara deskriptif.

\section{HASIL DAN PEMBAHASAN}

\section{Penerapan Sanksi terhadap Tindak Pidana Narkotika dalam Putusan Nomor 564/PID.SUS/2018/PN.DPS}

Menurut Moeljatno (2007), tindak pidana adalah suatu perbuatan criminal atau terlarang yang dilarang oleh seseorang dengan dikenakan sanksi sesuai pelanggarannya. Sesuai dengan pendapat Moeljatno, tindak pidana adalah perbuatan yang melanggar hukum dan melanggar aturan yang nantinya akan dikenakan sanksi oleh pihak yang berwewenang terhadap orang yang dikatakan sebagai 
pelaku perbuatan pidana atau pelaku tindak pidana. Namun, harus ditekankan juga jika dalam keadaan seperti ini, yang melanggar aturan atau hukum akan mendapatkan sanksi yang berat juga sesuai dengan perbuatannya.

Di masa sekarang ini, Indonesia tidak saja menjadi tempat transit narkotika, namun telah berubah sebagai wilayah memasarkan obat terlarang. Semua kalangan menjadi prihatin atas hal ini karena penyalahgunaan narkotika menelan banyak korban, tidak hanya kalangan orang yang mampu namun sudah sampai pada masyarakat miskin di perkotaan dan di desa.

Kasus narkotika yang ada di dunia ini sangat membuat semua kaum khawatir akibat pelanggaran tersebut. Hal ini menimbulkan rusaknya reputasi masyarakat sebagai pelaku dan mencoreng nama baik dari orang ataupun keluarga si pelaku. Penyalahgunaan narkoba saat ini tidak hanya melibatkan siswa sekolah dan universitas, tetapi juga telah menyebar ke anak-anak seperti siswa sekolah dasar. Padahal, narkotika di Indonesia adalah obat yang sangat dibutuhkan dalam pelayanan kesehatan, sehingga ketersediaannya harus terjamin.

Narkotika berasal dari bahasa Inggris "narcotics" yang artinya obat bius. Narkotika dapat diartikan sebagai bahan yang berasal dari 3 (tiga) jenis tanaman, yaitu papaper somniferum (candu erythroxyion), coca (kokain), dan cannabis sativa (ganja) baik murni maupun bentuk campuran. Adapun cara kerja narkotika adalah mempengaruhi susunan saraf yang dapat membuat seseorang tidak merasakan apa- apa, bahkan bila bagian tubuh kita disakiti sekalipun. Narkotika umumnya disebut sebagai penyalahgunaan jenis zat atau obat tertentu, yaitu zat yang dapat menimbulkan efek tertentu bagi mereka yang menggunakannya dengan menyuntikkannya ke dalam tubuh manusia. Efeknya dalam bentuk disuntik atau dibius adalah rasa sakit menjadi hilang, stimulasi pikiran, dan halusinasi atau delusi.

Narkotika adalah momok yang sangat menakutkan bagi kebanyakan orang, orang Indonesia dan bahkan komunitas global pada umumnya karena saat ini negara ini menghadapi situasi yang sangat mengkhawatirkan karena meningkatnya penggunaan narkotika atau narkotika ilegal, bahkan untuk berbagai narkotika agen dan zat psikotropika. Kekhawatiran ini diperburuk oleh perdagangan gelap obat-obatan terlarang dan psikotropika yang telah menyebar ke semua lapisan masyarakat, termasuk generasi muda. Ini akan memiliki implikasi besar bagi kehidupan rakyat, bangsa dan negara dan seterusnya. Terkait dengan kasus-kasus ini, fokusnya adalah pada penyalahgunaan narkoba yang saat ini yang telah mencapai situasi yang mengkhawatirkan bagi generasi muda, menjadikannya masalah nasional dan internasional yang mendesak dan harus diatasi dan dihentikan.

Dalam kehidupan bermasyarakat, tindakan kejahatan itu merupakan sesuatu hal yang dilarang oleh pemerintah. Tindakan tersebut bukan hanya sebagai larangan hukum, namun termasuk tindakan yang merupakan kelainan mental (Mustafa, 2007).

Peredaran narkotika saat ini bisa dikatakan begitu besar di tengah-tengah masyarakat. Jika di lihat dan dirasakan bahwa para mafia narkotika seakan-akan seperti tidak dapat terbendung lagi di negeri kita ini dan bahkan boleh dikatakan bahwa para mafia narkotika sudah meracuni bukan hanya pada masyarakat, bahkan sampai para oknum penegak hukum yang juga sebagai pengguna maupun ikut sebagai pemain untuk mendapatkan penghasilan ekonomis sebagai pengedar di tengah-tengah masyarakat. Itu telah terbukti jatuh ke bangsa Indonesia walaupun sejatinya seluruh bangsa mengalami kejahatan ini, dan seluruh dunia pada umumnya terkadang tidak habis pikir dan merasa terkejut dengan pemberitaan bahwa ada oknum-oknum pejabat pemerintah yang ikut tertangkap sebagai pelaku penyalahgunaan bahkan sebagai pengedar obat-obat terlarang khusunya narkotika.

Tingkat peredaran penggunaan narkotika hingga saat ini masih sangat tinggi dan semakin merajalela. Hingga saat ini kegiatan tersebut melibatkan seluruh masyarakat dengan berbagai kaum mulai remaja hingga dewasa. Beberapa hasil yang telah memperlihatkan dampak negatif dari penyalahgunaan narkotika diakibatkan oleh suatu kejahatan yang sangat amat berbahaya bagi setiap orang. Karena jika sudah terjerumus ke dalam larangan tersebut, akan susah keluar dari kejahatan itu. Dan, tentu ini berdampak buruk bagi kesehatan, sosial, dan budaya.

Untuk itu sanksi yang luar biasa sangat diperlukan untuk jenis kejahatan yang sangat luar biasa dan menakutkan bagi seluruh bangsa-bangsa di dunia ini. Tindakan ini merupakan kriminal transnasional yang artinya bahwa tindakan kriminal yang dilakukan dengan menggunakan jaringan dan jalur-jalur yang melibatkan banyak negara. Penerapan sanksi pidana narkotika yang khususnya dalam putusan nomor 564/Pid.Sus/2018/PN.DPS sudah sesuai dengan apa yang tertuang dalam Undang-Undang No. 35 Tahun 2009 tentang Narkotika dengan berbagai jeratan pasal dan sanksi 
hukum yang keras sesuai dengan pelanggarannya sebagai bukti keseriusan pemerintah dalam memberikan efek jera, menjaga, menanggulangi serta menyelamatkan atau melindungi generasi bangsa dari bahaya narkotika.

Langkah yang diupayakan untuk menghadapi permasalahan narkotika tidak hanya diupayakan dari segi ketersediaan tetapi juga segi permintaanpun diupayakan. Dilihat dari kepentingan nasional, kepastian dan keadilan hukum harus terjamin sebagai langkah untuk menegakkan hukum dan mengatasi beredarnya narkotika dan psikotropika karena para pelaku kejahatan lintas batas teritorial Indonesia saling terlibat satu sama lain. Selain itu, demi kepentingan nasional, khususnya demi kepentingan domestik, kepastian hukum dan utilitas akan diperoleh dalam pengaturan distribusi obatobatan narkotika dan zat psikotropika untuk keperluan perawatan hukum dan ilmu kepentingan umum (Mulyadi, 2011).

Pada awal sejarahnya narkotika hanya di gunakan sebagai alat bagi upacara- upacara ritual keagaman dan pengobatan, adapun jenis narkotika pertama yang digunakan adalah candu atau yang lebih dikenal dengan madat atau opium. Sejalan dengan perkembangan jaman kolonial maka perdagangan narkotika semakin tumbuh subur dan pemakainya sebagian besar dipakai oleh kalangan etnis cina, dimana jenis narkotika ketika itu terutamanya beredar di Negara-negara jajahan, termasuk Indonesia yang kala itu berada di bawah kekuasaan pemerintahan kolonial Belanda yang memberikan narkotika untuk kepentingan politiknya menjajah Negara Republik Indonesia (Adi, 2015).

Kehidupan komunitas pada akhirnya menuntut orang untuk membuat aturan hidup yang dipertahankan di antara mereka sebagai alat untuk menjaga hubungan yang harmonis dan kehidupan komunitas yang amandan damai. Kehidupan manusia sering dihadapkan dengan kebutuhan mendesak, kebutuhan untuk pengembangan diri, dan bahkan pemeliharaan status diri. Secara umum, kebutuhan setiap orang akan terpenuhi meskipun tidak sepenuhnya untuk orang lain. Untuk kebutuhan mendesak dan harus segera dipenuhi, seringkali dilakukan dengan pikiran yang tidak matang dan tanpa berpikir bahwa tindakan seperti itu berbahaya bagi diri mereka sendiri atau merugikan orang lain.

Pemikiran yang tidak matang itulah yang membuat manusia melakukan pelanggaran yang menimbulakn kerugian bagi seluruh masyarakat. Tanpa mereka sadari bahwa hal tersebut adalah perilaku yang dilarang, dan merugikan banyak orang. Dalam hukum pidana mengatur tentang bagaimana seseorang merugikan orang lain dan bagaimana seseorang tersebut dapat bertanggung jawab atas kesalahan yang dibuatnya. Sebagaimana diketahui bahwa dalam setiap pemeriksaan melalui proses acara pidana, keputusan hakim haruslah selalu didasarkan atas surat pelimpahan perkara yang memuat seluruh dakwaan atas kesalahan terdakwa.

\section{Pertimbangan Hakim pada Penerapan Sanksi dalam Putusan Tindak Pidana Narkotika dalam Putusan Nomor 564/PID.SUS/2018/PN.DPS}

Dalam pelanggaran narkotika, yang berhak untuk memeriksa dan mengadili perkara atau permasalahan itu ialah pihak yang berwewenang yang disebut dengan Hakim. Hakimlah yang memproses segala keperluan dan proses pada saat dilaksanakannya sidang, tanpa mengurangi aturan dan hukum yang tercantum pada undang-undang kehakiman utuk keadilan bagi setiap warga negara yang membutuhkan pembuktian akan keadilan. Dalam rangka melaksanakan tugas menyelesaikan suatu tindak pidana, seorang hakim sering memerlukan waktu yang lama untuk bisa menyelesaikan satu perkara di pengadilan.

Banyak faktor yang menyebabkan hakim sulit menjatuhkan putusan, diantaranya: perkara disembunyikan oleh pembela, saksi yang memberikan keterangan berbelit-belit, dan juga terdapat pertentangan keterangan dari saksi-saksi yang diajukan, kemudian bukti maetril yang tidak lengkap yang dibutuhkan sebagai alat bukti dalam persidangan.

Hakim memiliki peranan penting dalam suatu pengadilan karena hakimlah yang diberikan wewenang oleh pemerintah. Dalam menentukan kedudukan yang sesuai dengan peraturan perundangundangan dan undang-undang, hakimlah yang memiliki wewenang penuh atas hal tersebut. Hakim juga memiliki kewajiban yang yang harus dijalani demi tercapainya tujuan hukum tersebut. Serta demi kehidupan masyarakat yang adil makmur dan sentausa, hakim harus menuangkan prinsip-prinsip keadilan di dalam tugas yang ia kerjakan.

Tujuan putusan bebas yang terdapat dalam pemeriksaan perkara pidana adalah untuk memutuskan suatu perkara sebagai alat bukti yang kuat dan tidak jauh dari suatu aturan hukum yang sangat ditekankan dalam suatu undang-undang tanpa mengurangi rasa tanggung jawab si pelaku. 
Hingga saat, hukum itu yang berlaku tentu saja mempunyai tujuan yang jelas. Untuk mencapai tujuan hukum tersebut, sangat ditekankan kunci utama yang terletak pada penegak hukum itu sendiri.

Seorang hakim diwajibkan untuk menegakkan hukum dan keadilan dengan tidak memihak, dan juga seorang hakim dalam memutus suatu perkara harus teliti dalam menelaah permasalahan hukum yang ditangani terutama sebagai pembenaran yang akan dipublikasikan terhadap si pelaku. Setelah itu, hakim baru dapat menjatuhkan putusan terhadap peristiwa tersebut.

Pertimbangan-pertimbangan tersebut bukan hanya dari peraturan perundang-undangan, melainkan juga berdasarkan penglihatan hakim akan cara dan tingkah laku terdakwa, melihat adanya rasa penyesalan atau tidak, dan keyakinan hakim dalam membaca pikiran terdakwa untuk mengulangi atau tidaknya perbuatan yang pernah dilakukan. Hal itu menjadi pertimbangan khusus oleh para hakim dalam memutuskan hukuman yang layak dan seadil-adilnya untuk setiap orang yang didakwa melakukan perbuatan penyalahgunaan obat-obatan terlarang dalam hal ini narkotika. Pertimbangan hakim dalam menjatuhkan putusan terhadap tindak pidana narkotika dalam putusan nomor 564/Pid.Sus/2018/PN.DPS telah sesuai dengan berdasarkan pada keterangan saksi-saksi, barang bukti, dimana pembuktian memerlukan alat bukti minimal 2 (dua) untuk mempertimbangkan suatu fakta yang ada dalam persidangan, serta dibantu dengan keputusan hakim yang nantinya akan memutuskan suatu perkara tersebut.

\section{SIMPULAN DAN SARAN}

\section{Simpulan}

Berdasarkan hasil dan pembahasan yang telah diuraikan di atas, ada beberapa simpulan yang dapat dibuat, yaitu: pertama, penerapan sanksi pidana narkotika yang khususnya dalam putusan nomor 564/Pid.Sus/2018/PN.DPS sudah sesuai dengan apa yang tertuang dalam Undang-Undang No. 35 Tahun 2009 tentang Narkotika dengan berbagai jeratan pasal dan sanksi hukum yang keras sesuai dengan pelanggarannya sebagai bukti keseriusan pemerintah dalam memberikan efek jera, menjaga, menanggulangi serta menyelamatkan atau melindungi generasi bangsa dari bahaya narkotika. Kedua, pertimbangan hakim dalam menjatuhkan putusan terhadap tindak pidana narkotika dalam putusan nomor 564/Pid.Sus/2018/PN.DPS telah sesuai dengan berdasarkan pada keterangan saksi-saksi, barang bukti, dimana pembuktian memerlukan alat bukti minimal 2 (dua) untuk mempertimbangkan suatu fakta yang ada dalam persidangan, serta dibantu dengan keputusan hakim yang nantinya akan memutuskan suatu perkara tersebut.

\section{Saran}

Ada juga beberapa saran yang perlu disampaikan berdasarkan hasil dan pembahasan penelitian ini, yaitu: pertama dalam penerapan sanksi terhadap tindak pidana narkotika, aparat penegak hukum di antaranya Badan Narkotika Nasional (BNN), Polisi, Jaksa dan Hakim wajib memberikan atau membuat satu kesatuan sistem penanganan prosedur yang di dasari oleh Undang-Undang Republik Indonesia Nomor 35 tahun 2009 tentang Narkotika agar sepaham atau tidak tumpang tindih dengan tindakan yang patut dilakukan dalam penanganan kasus tindak pidana narkotika. Kedua, hakim dalam menjatuhkan putusan diharapkan mempertimbangkan dengan segala bentuk perbuatan terdakwa selama di dalam persidangan agar dapat memberikan putusan yang lebih adil bagi terdakwa yang telah bertobat dan menyesali perbuatannya serta mengklasifikasikan jenis pidana sesuai pelanggaran dan kesalahan yang terdapat dalam pasal-pasal tindak pidana narkotika.

\section{DAFTAR PUSTAKA}

Adi, K. (2015). Diversi Tindak Pidana Narkotika Anak. Malang: Setara Press.

Amanda, M. P., Humaedi, S., \& Santoso, M. B. (2017). Penyalahgunaan Narkoba di Kalangan Remaja. Prosiding Penelitian Dan Pengabdian Kepada Masyarakat, 4(2), 129-389.

Asyharudddin, M., Badaru, B., \& Hidjaz, M. K. (2020). Analisis Sanksi Pidana terhadap Pelaku Tindak Pidana Narkotika. Pleno Jure, 9(1), 58-71.

Moeljatno. (2007). Asas-Asas Hukum Pidana. Jakarta: Bina Aksara.

Mulyadi, M. (2011). Politik Hukum Pidana. Sumatera Utara: Bahan-bahan kuliah Fakultas Hukum Universitas Sumatera Utara.

Mustafa, M. (2007). Krimonologi: Kajian Sosiologi terhadap Kriminalitas, Perilaku Menyimpang dan Pelanggar Hukum. Depok: FISIP UI Press. 
Nurmaya, A. (2016). Penyalahgunaan Napza di Kalangan Remaja (Studi Kasus pada 2 Siswa di MAN 2 Kota Bima). Jurnal Psikologi Pendidikan \& Konseling, 2(1), 26-32.

Suyatna, U. (2018). Evaluasi Kebijakan Narkotika di Indonesia. Sosiohumaniora, 20(2), 168-176. Taufik, M. M., \& Suhasril. (2005). Tindak Pidana Narkotika (2nd ed.). Bogor: Ghalia Indonesia. Yamin, M. (2012). Tindak Pidana Khusus (1st ed.). Bandung: Pustaka Setia. 